Research, part of a Special Feature on A Social-Ecological Analysis of Diversified Farming Systems: Benefits, Costs, Obstacles, and Enabling Policy Frameworks

\title{
Rural Social Movements and Agroecology: Context, Theory, and Process
}

\author{
Peter M. Rosset $^{1,2}$ and Maria Elena Martínez-Torres ${ }^{3}$
}

\begin{abstract}
Rural social movements have in recent years adopted agroecology and diversified farming systems as part of their discourse and practice. Here, we situate this phenomenon in the evolving context of rural spaces that are increasingly disputed between agribusiness, together with other corporate land-grabbers, and peasants and their organizations and movements. We use the theoretical frameworks of disputed material and immaterial territories and of re-peasantization to explain the increased emphasis on agroecology by movements in this context. We provide examples from the farmer-to-farmer movement to show the advantages that social movements bring to the table in taking agroecology to scale and discuss the growing agroecology networking process in the transnational peasant and family farmer movement La Vía Campesina.
\end{abstract}

Key Words: agroecology; disputed territories; farmer-to-farmer; re-peasantization; social movements; Via Campesina

\section{INTRODUCTION}

At the beginning of the 21st century, the rural areas of the world constitute spaces that are hotly contested by different actors with opposing interests. Organizations and social movements of rural peoples, i.e., peasants, family farmers, indigenous people, rural workers and the landless engaged in land occupations, rural women, and others, increasingly use agroecology (Wezel et al. 2009, LVC 2010a, Altieri and Toledo 2011, Rosset et al. 2011), based on diversified farming systems, as a tool in the contestation, defense, (re) configuration, and transformation of contested rural spaces into peasant territories in a process that has been termed repeasantization (Fernandes 2009, van der Ploeg 2008, 2010). In contrast, financial capital, transnational corporations, and domestic private sectors are re-territorializing spaces that have abundant natural resources through mega-projects such as dams (Ferradas 2000, World Commission on Dams 2000), large-scale strip mining (Bebbington 2007, Holt-Giménez 2007), and monoculture plantations (Emanuelli et al. 2009). These corporate interests, aided by neoliberal economic policies and laws, have generated the growing land-grabbing problem in many southern countries (GRAIN 2009, Zoomers 2010, Hall 2011, Rosset 2011).

Here, we seek to provide a framework for understanding the increasing adoption of agroecological farming and diversified farming systems by rural social movements. We first paint the changing rural context in broad strokes and then provide a theoretical framework for understanding how this has translated into an increased emphasis on agroecology in both the practice and discourse of social movements as they seek greater autonomy and control over their territory and try to bring agroecology to scale. Finally, we illustrate this with examples from the farmer-to-farmer movement and from organizations belonging to the transnational peasant movement La Vía Campesina (LVC).

\section{CONTEXT: RENEWED CAPITAL FLOWS INTO RURAL AREAS}

In recent decades, neoliberal policies, characterized by deregulation, privatization, open markets, and free trade, have opened avenues for transnational financial capital and transnational corporations to invest in new and old enterprises worldwide. The collapses of the mortgage, dot-com, biotechnology, finance bank, and other speculative bubbles have helped usher in the first generalized world economic crisis of this century (Cox 2008, Stédile 2008, Rosset 2009). This has created a somewhat desperate search for new investment opportunities, pushing investors to look south increasingly, especially focusing on rural natural resources. This is driving a new boom of export crops, agrofuels, mining, and industrial monoculture plantations (Humphreys 2003, Barney 2007, Stédile 2008, Rosset 2009, McMichael 2010). Although transnational agribusinesses already had a major presence in Latin America since at least the 1980s, for example (Burbach and Flynn 1980, Teubal 1987, Marsden and Whatmore 1994), this new wave of investment is much larger because of the bigger injection of crisis-driven capital. In most countries, both northern and southern, domestic corporations are being partially or totally bought by transnational corporations and finance banks, and/or are being newly (re) capitalized by large loans and investments so that they effectively become subsidiaries of large transnational lenders (Stédile 2008, Bruszt and Holzhacker 2009, McMichael 2009).

The recent wave of investment and capitalization is putting agribusiness and other sectors that exploit rural resources in direct and growing conflict with the peasantry and other rural peoples (Fernandes 2008a,b, Gerber et al. 2009), where each side represents a different model of development and way of life. Peasant agriculture follows a pattern typically based on short and decentralized circuits of production and

${ }^{1}$ Center for the Study of Rural Change in Mexico (CECCAM), ${ }^{2}$ University of Michigan at Ann Arbor, ${ }^{3}$ Center for Research and Graduate Education on Social Anthropology-Southeast Campus (CIESAS-Sureste) 
consumption, with strong links between food production and local and regional ecosystems and societies. Agribusiness, on the other hand, has a centralized pattern based on corporate producers of inputs, processors, and trading companies, with production that is de-contextualized and de-linked from the specificities of local ecosystems and social relations (van der Ploeg 2008). In this system, production and consumption are de-linked in both time and space, whereas operations act on a global scale, with strategic alliances between input suppliers, processers, traders, supermarket chains, and finance banks to form agrifood complexes in what McMichael $(2009,2010)$ and others call the corporate food system or regime and van der Ploeg $(2008,2010)$ calls food empires.

Social movements comprising peasants and other rural peoples are actively defending spaces from, and contesting them with, these agribusinesses and other private sector actors and their allies in governments. Because the private sector is typically transnational in nature, peasant social movements have increasingly organized into transnational alliances, the most important and largest example of which is LVC (Desmarais 2007, Martínez-Torres and Rosset 2008, 2010). LVC is a global alliance of organizations of family farmers, peasant farmers, indigenous people, landless peasants and farm workers, rural women, and rural youth, representing at least 200 million families worldwide.

Both agribusiness and rural social movements are attempting to re-territorialize spaces, that is, reconfigure them to favor their own interests, whether those are maximum extraction of profits or defending and building communities. A key aspect is that this involves not just a battle over land per se, but also very much a battle over ideas.

\section{THEORY: AGROECOLOGY, DISPUTED TERRITORIES, AND RE-PEASANTIZATION}

Definitions: agroecology and diversified farming systems Wezel et al. (2009) observe that the word agroecology is variously used to refer to a science, a movement, and a practice. In a book written by, and largely for, LVC, Machín Sosa et al. (2010:16, translated from the Spanish) similarly note:

For many, agroecology is a science: the science that studies and attempts to explain the functioning of agroecosystems. For others, the word agroecology refers to the principles - not recipes-that guide the agronomic and productive practices that permit the production of food and fiber without agrochemicals... For the social movements that make up La Vía Campesina, the concept of agroecology goes much farther than just ecological-productive principles. In addition to these, LVC incorporates social, cultural and political principles and goals into its concept of agroecology.
In the movement's position on sustainable peasant agriculture, LVC argues (LVC 2010a:2-3):

We can find examples of sustainable peasant and family farm agriculture all over the planet, though the names we use vary greatly from one place to another, whether agroecology, organic farming, natural farming, low external input sustainable agriculture, or others. In La Vía Campesina we do not want to say that one name is better than another, but rather we want to specify the key principles that we defend. Truly sustainable peasant agriculture comes from a combination of the recovery and revalorization of traditional peasant farming methods, and the innovation of new ecological practices... We do not believe that the mere substitution of 'bad' inputs for 'good' ones, without touching the structure of monoculture, is sustainable... The application of these principles in the complex and diverse realities of peasant agriculture requires the active appropriation of farming systems by peasants ourselves, using our local knowledge, ingenuity, and ability to innovate. We are talking about relatively small farms managed by peasant families and communities. Small farms permit the development of functional biodiversity with diversified production and the integration of crops, trees and livestock. In this type of agriculture, there is less or no need for external inputs, as everything can be produced on the farm itself.

Here, we see references to what in this special issue are called diversified farming systems (DFS) based on the integrated management of functional biodiversity. DFS fall somewhere under agroecological principles and agroecological practices and are a key part of what Machín Sosa et al. (2010) and Rosset et al. (2011) call agroecological integration. Furthermore, Holt-Giménez (2006) and Rosset et al. (2011) show clearly how the movement form of agroecology is key to bringing agroecological practices, including DFS, to scale; this will be examined in greater detail below.

Part of the broader definition of agroecology for LVC is to see it as a key pillar in, and inseparable from, the construction of food sovereignty, defined as (see http://www.foodsovereignty. org/FOOTER/Highlights.aspx):

...the right of peoples to healthy and culturally appropriate food produced through ecologically sound and sustainable methods, and their right to define their own food and agriculture systems. It puts the aspirations and needs of those who produce, distribute and consume food at the heart of food systems and policies rather than the demands of markets and corporations. It defends the interests and inclusion of the next generation. It offers a 
strategy to resist and dismantle the current corporate trade and food regime, and directions for food, farming, pastoral and fisheries systems determined by local producers and users. Food sovereignty prioritizes local and national economies and markets and empowers peasant and family farmer-driven agriculture, artisanal fishing, pastoralist-led grazing, and food production, distribution and consumption based on environmental, social and economic sustainability. Food sovereignty promotes transparent trade that guarantees just incomes to all peoples as well as the rights of consumers to control their food and nutrition. It ensures that the rights to use and manage lands, territories, waters, seeds, livestock and biodiversity are in the hands of those of us who produce food. Food sovereignty implies new social relations free of oppression and inequality between men and women, peoples, racial groups, social and economic classes and generations.

Social movements such as LVC are taking agroecology very seriously. One reason (additional reasons are explored below) is that when land is acquired through struggle, it is often degraded land. When peasants have used industrial farming practices, the land has also incurred significant degradadtion. Faced with this reality, peasants are finding ways to manage or recover soils and agroecosystems that have been severely degraded by chemicals, machines, excessive mechanization, and the loss of functional biodiversity caused by the indiscriminate use of Green Revolution technologies (Lal 2009). Severe degradation means that even the ability to mask underlying causes with ever higher doses of chemical fertilizers and pesticides is limited (Marenya and Barrett 2009), and the cost of doing so is, in any event, becoming prohibitive, as prices of petroleum-derived farm inputs have soared in recent years (USDA 2011). This often leaves agroecology and DFS as the only alternatives open to small farmers (LVC 2010a).

Here, we have chosen to use the word agroecology in preference to DFS, simply because we believe it to be the broader, more inclusive term for the following discussion.

\section{Agroecology and disputed territories}

The theoretical work of critical geographers in Brazil and elsewhere on contested territories helps in understanding territorial conflicts such as those between peasants and agribusiness (Escobar 2004, Fernandes 2008a,b, 2009, Fernandes et al. 2010, Martínez-Torres 2012; M. E. MartínezTorres, unpublished manuscript). Fernandes (2008a,b), for example, argues that social classes and relationships generate different territories and spaces that are reproduced under conditions of continual conflict; as a result, there are spaces of domination and spaces of resistance. Territorial disputes are carried out in all possible dimensions: economic, social, political, cultural, theoretical, and ideological. In the case of rural areas, this gives rise to disputes between grassroots social movements and agribusiness, with its government allies, over what Fernandes (2009) calls both material and immaterial territories.

The dispute over material territories refers to the struggle to access, control, use, and shape or configure land and physical territory consisting of communities, infrastructure, soil, water, biodiversity, air, mountains, valleys, plains, rivers, and coasts. The opposing extreme outcomes of this kind of dispute might be viewed as a landscape consisting of a mosaic of diversified peasant farms intermingled with community-managed forests vs. a region devoid of families, trees, or other biodiversity dedicated to enormous export monoculture plantations based on hired labor rather than peasant families (Perfecto et al. 2009).

For Fernandes (2009), immaterial territory refers to the terrain of ideas or theoretical constructs, and he posits that there are no material territories that are not associated with immaterial territories. Therefore, the dispute over real and tangible territories and the resources they contain necessarily goes hand in hand with the dispute over immaterial territories or the space of ideology and ideas (Bezner Kerr 2007, McMichael 2007, Fernandes 2009). Contestation over immaterial territories is characterized by the formulation and defense of concepts, theories, paradigms, and explanations, all of which are used to convince others. In other words, the power to interpret and to determine the definition and content of concepts is itself a territory in dispute (Fernandes 2009).

Agribusiness and its ideological and financial support infrastructure in the World Bank, governments, finance banks, think-tanks, and elite universities, as well as advertising agencies and media specialists, creates and puts forth a framing language of efficiency, productivity, economies of scale, trade liberalization, free markets, and the need to feed the world, to build the consensus needed in society to gain control over territories and (re)configure them for the needs of industrial agriculture and profit-taking (Nisbet and Huge 2007).

Rural social movements respond in this discursive battle over immaterial territories with framing arguments (see Benford and Snow 2000) based on the benefits of family-based diversified agroecological farming in terms of feeding the world with healthy local food, providing good stewardship of the rural environment, preserving cultural heritage and the peasant or family farm way of life, and promoting resilience to climate change (see Borras et al. 2008, LVC 2009, 2010a, Martínez and Rosset 2010, Starr et al. 2011). They also put forth a critique of agribusiness and industrial agriculture for producing unhealthy food and generating inequality, greenhouse gases, hunger, environmental devastation, genetically modified organism (GMO) contamination, 
pesticide poisoning, and the destruction and loss of rural cultures and livelihoods. In this struggle to (re)configure the immaterial territory of ideas and ideology, they seek to (re) construct a consensus in society for the defense of peasant and indigenous material territories against corporate landgrabbing, build support for land occupations by landless peasants, and change public policies toward food sovereignty, based on agrarian reform, local markets, and ecological farming (Desmarais 2007, Martínez-Torres and Rosset 2010, Martínez-Torres 2012).

It is important to note that agroecology is playing an increasingly central role for these social movements in both arenas of territorial dispute. In the discursive struggle, social movements contrast agroecological farming by peasants and family farmers with the destructive practices and unhealthy food produced by industrial agriculture and agribusiness. This becomes more difficult when agribusiness responds with organic, GMO-free, and other types of labeling games (Martínez-Torres 2006), in turn forcing social movements to draw ever finer and more political distinctions between true agroecology and corporate green-washing (e.g., LVC 2011d).

In the defense and/or conquest of material territory, e.g., through land occupations or policy victories in favor of land redistribution, there is a growing tendency to promote agroecological farming as part of (re)configuring a space as a clearly peasant or family farm territory. This promotion is part of the reconfiguration of both the material and immaterial territories. For example, Martínez-Torres (2012; M. E. Martínez-Torres, unpublished manuscript) recently analyzed the case of the Landless Workers' Movement (MST) in Brazil, which is one of the most important and militant peasant organizations in the Americas and a leading member of LVC. In the past, MST appealed to public opinion to back its occupations of the idle lands of absentee landlords based on the injustice of a few having more land than they could use while others went landless. However, recent waves of transnational investment have capitalized Brazilian agribusiness, which in turn is turning once idle land into export, pulp, and agrofuel monocrop plantations of soy, sugar cane, Eucalyptus, and pine, with associated environmental degradation caused by excessive use of chemicals and heavy machines, and the elimination of biodiversity. As idle lands dry up, the landless are left only with the option of occupying the productive lands of agribusiness. As a result, they have had to re-frame their arguments as they seek the support of public opinion. Now they do so by contrasting the ecological and social wasteland of agribusiness plantations (as green deserts) with a pastoral vision of agroecologically farmed peasant lands, conserving biodiversity, keeping families in the countryside, and producing healthy food for local markets (food sovereignty).

This example shows how social movements must promote and implement agroecology in a much more overtly politicized and ideological manner than do other actors in the sphere of alternative farming practices, e.g., nongovernmental organizations (NGOs), researchers, government agencies, and private companies. We say more overtly political and ideological because any technological choice brings political and ideological baggage with it. However, the fact that their use is politicized in no way means that the families who belong to these organizations and movements are not engaged in everyday practices of cultivation and harvest, nor that the organizations themselves are not involved in the complicated task of building processes to promote and support the transformation of productive practices. In promoting the transition from Green Revolution-style farming in which families depend on input markets to more autonomous agroecological farming, and thus reconfiguring spaces as peasant territories, social movements engage in the process of re-peasantization.

\section{Re-peasantization and agroecology}

Van der Ploeg (2008) put forth a theoretical proposition about the peasantries of today. Rather than defining peasant, he defines what he calls the peasant condition or the peasant principle, characterized by the constant struggle to build autonomy (van der Ploeg 2008:23):

Central to the peasant condition, then, is the struggle
for autonomy that takes place in a context
characterized by dependency relations, marginalization
and deprivation. It aims at and materializes as the
creation and development of a self-controlled and
self-managed resource base, which in turn allows
for those forms of co-production of man and living
nature that interact with the market, allow for
survival andforfurtherprospects andfeed back into
and strengthen the resource base, improve the
process of co-production, enlarge autonomy and,
thus reduce dependency... Finally, patterns of
cooperation are present which regulate and
strengthen these interrelations.

Two characteristics stand out in this definition. The first is that peasants seek to engage in co-production with nature in ways that strengthen their resource base (soil, biodiversity, etc.). The second is precisely the struggle for (relative) autonomy via the reduction of dependence in a world characterized by inequality and unequal exchange. According to van der Ploeg (2010), peasants may pursue agroecology to the extent that it permits them to strengthen their resource base and become more autonomous from input and credit markets, and thus indebtedness, while improving their conditions. This use of agroecology to move along a continuum from dependency toward relative autonomy, i.e., from being the entrepreneurial farmers they had become, in some cases, toward being peasants again, is one axis of what van der Ploeg (2008) calls re-peasantization. Another axis of re-peasantization is the conquest of land and territory from agribusiness and other 
large landowners, whether by land reform, land occupations, or other mechanisms.

The overall process of re-peasantization is analogous to the (re)configuration of space as peasant territory, and agroecology can be, and increasingly is, a part of both (Martínez-Torres 2012; M. E. Martínez-Torres, unpublished manuscript). When farmers undergo a transition from inputdependent farming to agroecology based on local resources, they are becoming more peasant. Agroecological practices are similar to, and frequently based upon, traditional peasant practices, so in this transition, re-peasantization takes place. And in marking the difference between the ecological and social wasteland of agribusiness land and ecological farming on land recovered by peasants, they are reconfiguring territories as peasant territories as they re-peasantize them through agroecology.

Conversely, when peasants are drawn into greater dependence, use of Green Revolution technologies, market relations, and the debt cycle, this is one axis of de-peasantization. Another axis of de-peasantization is when land-grabbing corporations or states displace peasants from their land and territories and reconfigure these as territories for agribusiness, mining, tourism, or infrastructure development.

Along similar lines, Sesia (2003) found in her research in Oaxaca that when market conditions and fluctuations generate situations in which the value of income from the sale of cash crops and family labor drops relative to the value of production for subsistence and family self-provisioning, peasant families would shift the mix of land devoted to coffee versus subsistence crops. She concurs with van der Ploeg in that repeasantization is based on reducing external dependence, part of an overall process that Barkin et al. (2009:40) call a "new communitarian rurality" because it also includes a renewed emphasis on cooperation and strengthening of rural communities.

The twin processes of re- and de-peasantization move back and forth over time as circumstances change (van der Ploeg 2008). During the heyday of the Green Revolution in the 1960 s and 1970s, the peasantry was incorporated en masse into the system, many becoming entrepreneurial family farmers (de Janvry 1981). However, today, faced with growing debt and market-driven exclusion, the net tendency is the reverse, according to van der Ploeg $(2008,2010)$. He presents convincing data to show that even those farmers in northern countries most integrated into the market are in fact taking (at least small) steps toward becoming more peasant through relatively greater autonomy from banks, input and machinery suppliers, and corporate middlemen. Some even become organic farmers. In other words, there is net retreat from some or many elements of the market (Muñoz 2008).

Numerical re-peasantization can be seen in the end of the longterm decline in the number of farms and the number of people dedicated to agriculture, and even a visible up-tick, in countries like the United States (U.S. Census Bureau 2010) and Brazil (Ministério do Desenvolvimento Agrário 2009). In fact, what one observes is an increase in both the number of small familysize farms and an increase in large-scale commercial farms (agribusiness), with a decline in the numbers of intermediate size classes. In other words, in today's world, we are essentially losing the middle (entrepreneurial farmers) to both re-peasantization and de-peasantization. We are also increasingly witness to a global territorial conflict, material and immaterial, between agribusiness and peasant resistance (van der Ploeg 2010; M. E. Martínez-Torres, unpublished manuscript). In this context, we see the post-1992 emergence of LVC as arguably the world's largest transnational social movement (Desmarais 2007, Martínez-Torres and Rosset 2010), promoting agroecologically diversified farming as a key element in resistance, re-peasantization, and the reconfiguration of territories (Sevilla Guzmán and Alier 2006, Sevilla Guzmán 2007). Of course, this somewhat stylized dichotomy should in no way be taken to imply that there is no longer a very significant number of medium-scale farmers who still maintain both agribusiness and peasant identities; there is.

\section{PROCESS: TAKING AGROECOLOGY TO SCALE}

A persistent debate in the literature on agroecological farming, and on the impact of agricultural research in general, has been the question of scaling out (broad adoption over wide areas and by many farmers) and scaling up (institutionalizing supportive policies for alternatives) successful experiences (von der Weid 2000, Holt-Giménez 2001, Pachicho and Fujisaka 2004, Altieri and Nicholls 2008, Rosset et al. 2011). This is paralleled in the literature concerning the effectiveness and appropriateness of conventional agricultural research and extension systems for reaching peasant families in general (Freire 1973), and more specifically, for promoting agroecology rather than the Green Revolution (e.g., Chambers 1990, 1993, Holt-Giménez 2006, Rosset et al. 2011).

While conventional top-down agricultural research and extension has shown a negligible ability to develop and achieve broad adoption of the practices of agroecological diversified farming, social movements and socially dynamizing methodologies appear to have significant advantages (Rosset et al. 2011). Social movements incorporate large numbers of people, in this case, large numbers of peasant families, in self-organized processes that can dramatically increase the rate of innovation and the spread and adoption of innovations.

The fact that agroecology is based on applying principles in ways that depend on local realities means that the local knowledge and ingenuity of farmers must necessarily take a front seat because farmers cannot blindly follow pesticide and fertilizer recommendations prescribed on a recipe basis by extension agents or salesmen. Methods in which the extensionist or agronomist is the key actor and farmers are 
passive are, in the best of cases, limited to the number of peasant families that can be effectively attended to by each technician because there is little or no self-catalyzed dynamic among farmers to carry innovations well beyond the last technician. Thus, these cases are finally limited by the budget, that is, by how many technicians can be hired. Many projectbased rural development NGOs face a similar problem. When the project funding cycle comes to an end, virtually everything reverts to the pre-project state, with little lasting effect (Rosset et al. 2011).

The most successful methodology for promoting farmer innovation and horizontal sharing and learning is the campesino-a-campesino (farmer-to-farmer or peasant-topeasant) methodology (CAC). Although the practice of farmers innovating and sharing goes back to time immemorial, the more contemporary and more formalized version was developed locally in Guatemala and spread through Mesoamerica beginning in the 1970s (Holt-Giménez 2006). CAC is a Freirian horizontal communication methodology (Freire 1970) or social process methodology that is based on farmer-promoters who have innovated new solutions to problems that are common among many farmers or who have recovered/rediscovered older traditional solutions and who use popular education methodology to share them with their peers, using their own farms as their classrooms. A fundamental tenet of CAC is that farmers are more likely to believe and emulate a fellow farmer who is successfully using a given alternative on their own farm than they are to take the word of an agronomist of possibly urban extraction. This is even more the case when they can visit the farm of their peer and see the alternative functioning with their own eyes. In Cuba, for example, farmers say "seeing is believing" (Rosset et al. 2011).

Whereas conventional extension can be demobilizing for farmers, CAC is mobilizing because they become the protagonists in the process of generating and sharing technologies. CAC is a participatory method based on local peasant needs, culture, and environmental conditions that unleashes knowledge, enthusiasm, and protagonism as a way of discovering, recognizing, taking advantage of, and socializing the rich pool of family and community agricultural knowledge that is linked to their specific historical conditions and identities. In conventional extension, the objective of technical experts all too often has been to replace peasant knowledge with purchased chemical inputs, seeds, and machinery in a top-down process in which education is more like domestication (Freire 1973, Rosset et al. 2011). HoltGiménez (2006) extensively documented the Mesoamerican CAC social movement experiences with $\mathrm{CAC}$ as a methodology for promoting agroecological farming practices, which he calls peasant pedagogy.

\section{AGROECOLOGY IN LA VÍA CAMPESINA}

Cuba is where the CAC social methodology achieved its greatest impact, when the National Association of Small Farmers (ANAP), a member of LVC, adopted it along with a conscious and explicit goal of building a grassroots movement for agroecology inside the national organization (extensively detailed in Machín Sosa at al. 2010 and Rosset et al. 2011). In less than ten years, the process of transforming systems of production into agroecological integrated and diversified farming systems had spread to more than one-third of all peasant families in Cuba, a remarkable rate of growth. During the same time period in which peasants became agroecological, the total contribution of peasant production to national production jumped dramatically, with other advantages in reduced use of farm chemicals and purchased off-farm inputs (more autonomy) and greater resiliency to climate shocks (Machín Sosa at al. 2010, Altieri and Toledo 2011, Rosset et al. 2011).

In southern India, a grassroots agroecological movement has grown rapidly and cuts across the bases of some member organizations of LVC, which is now facilitating exchanges with farmers from other countries across Asia (Babu unpublished manuscript http://www.atimysore.gov.in/PDF/ac tion_research1.pdf, Palekar undated). The Zero Budget Natural Farming (ZBNF) movement is partially a response to the acute indebtedness in which many India peasants find themselves. The debt is of course from the high production costs of conventional Green Revolution-style farming, as translated into budgets for bank credit, and is the underlying cause of the well-known epidemic of farmer suicides in that country (Mohanty 2005). The idea of ZBNF is to use agroecological practices based totally on resources found on the farm, such as mulching, organic amendments, and diversification, to break the stranglehold of debt on farming households by purchasing zero off-farm inputs. According to LVC farmer leaders in South Asia, several hundred-thousand peasant families have joined the movement.

In Zimbabwe, the Zimbabwe Organic Smallholder Farmer's Forum (ZIMSOFF) is a recent member of LVC. The current president of ZIMSOFF is an agroecology promoter from Shashe in the Masvingo agrarian reform cluster. Shashe is an intentional community created by formerly landless peasants who engaged in a 2-yr land occupation before being awarded the land by the governments' often maligned but basically misunderstood land reform program (see Scoones et al. 2010, Cliffe et al. 2011, and Moyo 2011 for excellent analyses of agrarian reform in Zimbabwe). A cluster of families in the community are committed to practicing and promoting diversified agroecological farming; through ZIMSOFF they are having national impact, and through LVC, international impact. When Shashe hosted a regional agroecology encounter in 2011 of LVC organizations from southern, central and 
eastern Africa, the participants noted in their final declaration (LVC 2011a):

We have been meeting at the Shashe Endogenous Development Training Centre in Masvingo Province, Zimbabwe to plan how to promote agroecology in our Region (Southern, Eastern \& Central Africa). Here we have been privileged to witness first hand the successful combination of agrarian reform with organic farming and agroecology carried out by local small-holder farming families. In what were once large cattle ranches owned by three large farmers who owned 800 head of cattle and produced no grain or anything else, there are now more than 365 small holder peasant farming families with more than 3,400 head of cattle, who also produce a yearly average of 1 to 2 tonnes of grain per family plus vegetables and other products, in many cases using agroecological methods and local peasant seeds. This experience strengthens our commitment to and belief in agroecology and agrarian reform as fundamental pillars in the construction of Food Sovereignty.

They also decided to establish an international agroecology training school in Shashe to train peasant activists from LVC organizations in the region as agroecology promoters using the CAC method.

These are examples of what is a burgeoning agroecology process in LVC and its member organizations. Part of the process (described in this section on the basis of participantobservation by the authors; see DeWalt and DeWalt 2002) has consisted of holding regional and continental "encounters of agroecology trainers." These have been held in the Americas (in 2009 and 2011); Asia (in 2010); southern, central, and eastern Africa (in 2011); West Africa (in 2011); and Europe (in 2012); as well as a first Global Encounter of Peasant Seed Farmers, held in Bali (in 2011). The declarations from some of these meetings illustrate the growing discursive place of agroecology in LVC (e.g., LVC 2011a,b,c).

This process has served several important purposes so far. One has been to help LVC collectively to realize the sheer quantity of ongoing experiences with agroecology and sustainable peasant agriculture that are currently underway inside member organizations at the national and regional levels. The vast majority of organizations either already have some sort of internal program to promote agroecology or they are currently discussing how to create one. Another purpose these encounters are serving is to elaborate detailed work plans to support these ongoing experiences and to link them with one another in a horizontal exchange and learning process. It also has been the space to construct collectively a shared vision of what agroecology means to LVC; that is the philosophy, political content, and rationale that links organizations in this work.

As participant-observers in this process, it has been possible for us to identify a number of clear, shared rationales for the transition to agroecological farming and local seeds among the peasant and farm families that belong to the member organizations of LVC and among the organizations themselves. Above all, the shared vision that is emerging views agroecology as a socially activating tool for the transformation of rural realities through collective action and as a key building block in the construction of food sovereignty.

Another central rationale is based on the relationship between peasants and nature. One can think of LVC as a space of encounter among different cultures, whether East and West; North and South; landed and landless; or Hindu, Muslim, Buddhist, Animist, Christian, and Atheist. Among these exchanges, one that has profoundly affected attitudes toward nature has been the encounter between the Indigenous and nonindigenous worlds inside LVC. The nonindigenous organizations have learned from Indigenous people about the importance of thinking in terms of territory rather than just land, and about the imperative to live in harmony and to take good care of the Mother Earth. The Indigenous people within LVC were the first to sound the alert about climate change, which is now a priority issue, and their influence is felt strongly in the growing rejection of industrial farming practices that "damage the Mother Earth" and in the consequent embracing of agroecology. A closely related rationale is the need to use agroecological practices to restore degraded soils. Here, one sees both the co-production with nature and the construction of peasant/indigenous territories, both material and immaterial, in which the Mother Earth is defended rather than injured.

Van der Ploeg's $(2008,2010)$ emphasis on the struggle for autonomy is echoed time and again as organizations and families stress the advantages offered by agroecology in terms of building relative autonomy from input and credit markets (by using on-farm resources rather than purchased inputs) and food markets (greater self-provisioning through mixing subsistence and market crops), and even by re-directing outputs toward local and ecological or organic markets where farmers have more influence and control (and thus greater autonomy from global markets). Not only are these clear steps toward re-peasantization, they are increasingly part of creating peasant territories.

Driven by these motivations and rationales, LVC and its members have in recent years set up CAC agroecology programs in many countries in the Americas, Asia, and Africa, have produced agroecology training materials, and have sponsored seed fairs and seed saving and exchange networks in a number of regions and countries. One enormously 
successful national peasant seed program has been developed in Cuba, under which farmers breed and select their own varieties; smaller scale programs have been developed in other countries. LVC has not only organized national and international exchanges so that farmers can see for themselves ("seeing is believing") and learn from the best cases, but it has also recently begun to identify, self-study, document, analyze, and horizontally share the lessons of the best cases of farmerled climate-robust agroecology and food sovereignty. LVC has opened regional agroecology training schools and/or peasant universities in Venezuela, Paraguay, Brazil, Nicaragua, Indonesia, and India, with others on the drawing board for Mozambique, Zimbabwe, Niger, and Mali; these are in addition to the establishment of dozens of national and subnational level schools.

LVC has also created political leadership training academies in many countries and several regions to prepare peasant leaders to pressure governments for needed policy changes. It has taken steps to engage on an ongoing, critical but constructive way with peasant-friendly policy makers in local, provincial, and national governments in diverse countries and with select programs and functionaries in international agencies to promote the implementation of alternative, more agroecology-, climate-, farmer-, and consumer-friendly public policies. In countries that have less friendly governments and policy makers, member organizations have organized massive mobilization of political pressure to encourage them to consider alternatives more seriously.

A number of LVC member organizations in the Americas, Asia, and Africa have peasant-owned and -run cooperative seed enterprises that multiply and distribute local seed varieties. Some of these and other member organizations have pressured and cooperated with other actors and local governments to open farmers' markets for ecologically produced food and experimented with other direct sales to consumer systems.

LVC believes that it now has a sufficient number of pioneering experiences underway, particularly in training, to be able to synergize them effectively and achieve a significantly enhanced multiplier effect and scaling out and scaling up of agroecology. LVC plans to do this by integrating and networking them into regional systems for experience and lesson exchanges, mutual support, and coordinated lobby and pressure work to push governments to implement policies more favorable to peasant farming, agroecology, and food sovereignty, and by extension, re-peasantization and the construction of peasant territories.

In the continual dispute over the immaterial territory of agroecology, the latest arena is that of solutions to climate change. LVC has been actively denouncing so-called false solutions to climate change such as agrofuels, GMOs, carbon markets, and REDD and REDD+ (LVC 2010b) and has more recently sounded the alarm about the possible co-option of agroecology by the World Bank and others via the creation of soil carbon markets, using slogans such as "Our carbon is not for sale" and "Agroecology is not for sale" (LVC 2011d).

\section{CONCLUSIONS}

The theoretical frameworks of disputed territories and repeasantization help us to understand the empirical phenomenon of the growing interest, practice, and discourse of agroecology among rural social movements, especially LVC, in the context of growing corporate land-grabbing and rising input costs. For peasants and family farmers and their movements, agroecology helps build autonomy from unfavorable markets and restore degraded soils, and social processes and movements help bring these alternatives to scale. Finally, this (re)invention of peasant practices is part of the (re)configuration of contested material and immaterial spaces as peasant territories in the process of re-peasantization.

Responses to this article can be read online at: http://www.ecologyandsociety.org/voll7/iss3/art17/ responses/

\section{Acknowledgments:}

We thank the peasants and family farmers of La Via Campesina for showing the way toward a better life in the countryside with respect for human dignity and Mother Earth.

\section{LITERATURE CITED}

Altieri, M. A., and C. I. Nicholls. 2008. Scaling up agroecological approaches for food sovereignty in Latin America. Development 51(4):472-480. http://dx.doi.org/10.10 57/dev.2008.68

Altieri, M. A., and V. M. Toledo. 2011. The agroecological revolution in Latin America: rescuing nature, ensuring food sovereignty and empowering peasants. Journal of Peasant Studies 38(3):587-612. http://dx.doi.org/10.1080/03066150.2 $\underline{011.582947}$

Barkin, D., M. E. Fuente, and M. Rosas. 2009. Tradición e innovación. Aportaciones campesinas a la orientación de la innovación tecnológica para forjar sustentabilidad. Trayectorias 11(29):39-54.

Barney, K. 2007. Power, progress and impoverishment: plantations, hydropower, ecological change and community transformation in Hinboun District, Lao PDR. York Center for Asian Research Papers 1. York Center for Asian Research, Toronto, Canada. [online] URL: http://www.rightsandresources. org/publication_details.php?publicationID=129.

Bebbington, A., editor. 2007. Minería, movimientos sociales y respuestas campesinas: una ecología política de 
transformaciones territoriales. Instituto de Estudios Peruanos, Lima, Peru.

Benford, R. D., and D. A. Snow. 2000. Framing processes and social movements: an overview and assessment. Annual Review of Sociology 26:611-639. http://dx.doi.org/10.1146/an nurev.soc.26.1.611

Bezner Kerr, R. 2007. The land is changing: contested agricultural narratives in northern Malawi. Pages 98-115 in P. McMichael, editor. Contested development: critical struggle for social change. Routledge, New York, New York, USA.

Borras, S. M. Jr., M. Edelman, and C. Kay. 2008. Transnational agrarian movements: origins and politics, campaigns and impact. Journal of Agrarian Change 8 (2-3):169-204. http://dx.doi.org/10.1111/j.1471-0366.2008.00167. $\underline{\mathrm{x}}$

Bruszt, L., and R. Holzhacker, editors. 2009. The transnationalization of economies, states, and civil societies: new challenges for governance in Europe. Springer, New York, New York, USA.

Burbach, R., and P. Flynn. 1980. Agribusiness in the Americas. Monthly Review Press, New York, New York, USA.

Chambers, R. 1990. Farmer-first: a practical paradigm for the third agriculture. Pages 237-244 in M. A. Altieri and S. B. Hecht, editors. Agroecology and small farm development. CRC Press, Boca Raton, Florida, USA.

Chambers, R. 1993. Challenging the professions: frontiers for rural development. Intermediate Technology Publications, London, UK.

Cliffe, L., J. Alexander, B. Cousins, and R. Gaidzanwa. 2011. An overview of fast track land reform in Zimbabwe: editorial introduction. Journal of Peasant Studies 38(5):907-938. http: //dx.doi.org/10.1080/03066150.2011.643387

Cox, R. W. 2008. Transnational capital, the US State and Latin American trade agreements. Third World Quarterly 29 (8):1527-1544. http://dx.doi.org/10.1080/01436590802528598

De Janvry, A. 1981. The agrarian question and reformism in Latin America. Johns Hopkins University Press, Baltimore, Maryland, USA.

Desmarais, A. A. 2007. La Vía Campesina: globalization and the power of peasants. Fernwood Publishing, Halifax, Canada.

DeWalt, K. M., and B. R. DeWalt. 2002. Participant observation: a guide for fieldworkers. AltaMira Press, Walnut Creek, California, USA.

Emanuelli, M. S., J. Jonsén, and S. M. Suárez, editors. 2009. Red sugar, green deserts: Latin American report on monocultures and violations of the human rights to adequate food and housing, to water, to land and to territory. FIAN International, Heidelberg, Germany. [online] URL: http://ww w.fian.org/resources/documents/others/red-sugar-green-desertsreport-on-monocultures-and-human-rights/pdf.

Escobar, A. 2004. Development, violence and the new Imperial order. Development 47(1):15-21. http://dx.doi.org/1 0.1057/palgrave.development.1100014

Fernandes, B. M. 2008a. Questão agraria: conflictualidade e desenvolvimento territorial. Pages 173-224 in A. M. Buainain, editor. Luta pela terra, reforma agraria e gestão de conflitos no Brasil. Editora Unicamp, Campinas, Brazil.

Fernandes, B. M. 2008b. Entrando nos territórios do territoório. Pages 273-301 in E. T. Paulino and J. E. Fabrini, editors. Campesinato e territórios em disputas. Expressão Popular, Sao Paulo, Brazil.

Fernandes, B. M. 2009. Sobre a tipologia de territórios. Pages 197-215 in M. A. Saquet and E. S. Sposito, editors. Territórios e territorialidades: teoria, processos e conflitos. Expressão Popular, Sao Paulo, Brazil.

Fernandes, B. M., C. A. Welch, and E. C. Gonçalves. 2010. Agrofuel policies in Brazil: paradigmatic and territorial disputes. Journal of Peasant Studies 37(4):793-819. http://dx. doi.org/10.1080/03066150.2010.512459

Ferradas, C. 2000. Report of social impacts of dams: distributional and equity issues, Latin American region. World Commission on Dams, Cape Town, South Africa. [online] URL: http://oldwww.wii.gov.in/eianew/eia/dams\%20and\% 20development/kbase/contrib/soc204.pdf.

Freire, P. 1970. Pedagogy of the oppressed. Herder and Herder, New York, New York, USA.

Freire, P. 1973. Extension or communication? McGraw, New York, New York, USA.

Genetic Resources Action International (GRAIN). 2009. The new farm owners: corporate investors lead the rush for control over overseas farmland. Genetic Resources Action International, Barcelona, Spain. [online] URL: http://www.gr ain.org/article/entries/4389-the-new-farm-owners-corporate-investorslead-the-rush-for-control-over-overseas-farmland.pdf.

Gerber, J.-F., S. Veuthey, and J. Martínez-Alier. 2009. Linking political ecology with ecological economics in tree plantation conflicts in Cameroon and Ecuador. Ecological Economics 68 (12):2885-2889. http://dx.doi.org/10.1016/j.ecolecon.2009.06.029

Hall, D. 2011. Land grabs, land control, and Southeast Asian crop booms. Journal of Peasant Studies 38(4):837-857. http: //dx.doi.org/10.1080/03066150.2011.607706

Holt-Giménez, E. 2001. Scaling up sustainable agriculture: lessons from the Campesino a Campesino movement. LEISA 
Magazine 3(3):27-29. [online] URL: http://www.agricultures network.org/magazines/global/lessons-in-scaling-up/scalingup-sustainable-agriculture/at download/article pdf.

Holt-Giménez, E. 2006. Campesino a campesino: voices from Latin America's farmer to farmer movement for sustainable agriculture. Food First Books, Oakland, California, USA.

Holt-Giménez, E. 2007. Land-gold_reform: the territorial restructuring of Guatemala's highlands. Development Report 16. Institute for Food and Development Policy, Oakland, California, USA. [online] URL: http://www.foodfirst.org/files/ pdf/Dr\%2016\%20Land-Gold-Reform\%20-\%20Full.pdf.

Humphreys, D. 2003. Life protective or carcinogenic challenge? Global forests governance under advanced capitalism. Global Environmental Politics 3(2):40-55. http:// dx.doi.org/10.1162/152638003322068209

La Vía Campesina (LVC). 2009. Small scale sustainable farmers are cooling down the Earth. La Vía Campesina, Jakarta, Indonesia. [online] URL: http://viacampesina.net/dow nloads/PAPER5/EN/paper5-EN.pdf.

La Vía Campesina (LVC). 2010a. Sustainable peasant and family farm agriculture can feed the world. La Vía Campesina, Jakarta, Indonesia. [online] URL: http://viacampesina.org/do wnloads/pdf/en/paper6-EN-FINAL.pdf.

La Vía Campesina (LVC). 2010b. ;Miles de soluciones construye el pueblo ante el cambio climãtico! La Vía Campesina, Jakarta, Indonesia. [online] URL: http://www.via campesina.org/sp/index.php?option=com content $\&$ view $=$ article \&id=1056:imiles-de-soluciones-construye-el-pueblo-anteel-cambio-climatico\&catid=46: cambios-climcos-y-agrocombustibles\&Itemid=79.

La Vía Campesina (LVC). 2011a.1st encounter of agroecology trainers in Africa region 1 of La Vía Campesina. La Vía Campesina, Jakarta, Indonesia. [online] URL: http://v iacampesina.org/en/index.php?option=com_content\&view= article\&id=1098:1st-encounter-of-agroecology-trainers-in-africaregion-1-of-la-via-campesina-\&catid=23:agrarian-reform\&Itemid=36

La Vía Campesina (LVC). 2011b. Peasant seeds: dignity, culture and life. Farmers in resistance to defend their right to peasant seeds. La Vía Campesina, Jakarta, Indonesia. [online] URL: http://viacampesina.org/en/index.php?option= com_content\&view=article\&id=1057:peasant-seeds-dignityculture-and-life-farmers-in-resistance-to-defend-their-right-topeasant-seeds\&catid=22:biodiversity-and-geneticresources\&Itemid $=37$.

La Vía Campesina (LVC). 2011c. 2nd Latin American encounter on agroecology: final declaration. La Vía Campesina, Jakarta, Indonesia. [online] URL: http://viacamp esina.org/en/index.php?option=com content $\& v i e w=$ article\&id=1105:2nd-latin-american-encounter-onagroecology\&catid=23: agrarian-reform\&Itemid=36.

La Vía Campesina (LVC). 2011d. La Vía Campesina: call to Durban. La Vía Campesina, Jakarta, Indonesia. [online] URL: http://viacampesina.org/en/index.php?option=com content\&view= article\&id=1109:la-via-campesina-call-to-durban\&catid=48:climate-change-and-agrofuels\&Itemid $=75$.

Lal, R. 2009. Soil degradation as a reason for inadequate human nutrition. Food Security 1:45-57. http://dx.doi.org/10. 1007/s12571-009-0009-z

Machín Sosa, B., A. M. Roque Jaime, D. R. Ávila Lozano, and P. M. Rosset. 2010. Revolución agroecológica: el movimiento de Campesino a Campesino de la ANAP en Cuba. Cuando el campesino ve, hace fe. ANAP and La Vía Campesina, Havana, Cuba, and Jakarta, Indonesia. [online] URL: http://www.viacampesina.org/downloads/pdf/sp/2010-04-14rev-agro.pdf.

Marenya, P. P., and C. B. Barrett. 2009. State-conditional fertilizer yield response on western Kenyan farms. American Journal of Agricultural Economics 91(4):991-1006. http://dx. doi.org/10.1111/j.1467-8276.2009.01313.x

Marsden, T. K., and S. Whatmore. 1994. Finance capital and food system restructuring: national incorporation of global dynamics. Pages 107-128 in P. McMichael, editor. The global restructuring of agro-food systems. Cornell University Press, Ithaca, New York, USA.

Martínez-Torres, M. E. 2006. Organic coffee: sustainable development by Mayan farmers. Ohio University Press, Athens, Ohio, USA.

Martínez-Torres, M. E. 2012. Territorios disputados: tierra, agroecologia y recampesinización. Movimientos sociales rurales en Latinoamerica y agronegocio. Paper presented at the 2012 Conference of the Latin American Studies Association, San Francisco, California, 23-26 May 2012. [online] URL: http://lasa.international.pitt.edu/members/congresspapers/lasa2012/files/4305.pdf.

Martínez-Torres, M. E., and P. M. Rosset. 2008. La Vía Campesina: transnationalizing peasant struggle and hope. Pages 307-322 in R. Stahler-Sholk, H. E. Vanden, and G. D. Kuecker, editors. Latin American social movements in the twenty-first century: resistance, power, and democracy. Rowman \& Littlefield, Lanham, Maryland, USA.

Martínez-Torres, M. E., and P. M. Rosset. 2010. La Vía Campesina: the birth and evolution of a transnational social movement. Journal of Peasant Studies 37(1):149-175. http:// dx.doi.org/10.1080/03066150903498804

McMichael, P., editor. 2007. Contested development: critical struggle for social change. Routledge, New York, New York, USA. 
McMichael, P. 2009. A food regime genealogy. Journal of Peasant Studies 36(1):139-169. http://dx.doi.org/10.1080/030 $\underline{66150902820354}$

McMichael, P. 2010. Agrofuels in the food regime. Journal of Peasant Studies 37(4):609-629. http://dx.doi.org/10.1080/0 $\underline{3066150.2010 .512450}$

Ministério do Desenvolvimento Agrário. 2009. Agricultura familiar no Brasil e o Censo Agropecuário 2006. Ministério do Desenvolvimento Agrário, Brasilia, Brazil.

Mohanty, B. B. 2005. 'We are like the living dead': farmer suicide in Maharashtra, western India. Journal of Peasant Studies 32(2):243-276. http://dx.doi.org/10.1080/0306615050 $\underline{0094485}$

Moyo, S. 2011. Three decades of agrarian reform in Zimbabwe. Journal of Peasant Studies 38(3):493-531. http:// dx.doi.org/10.1080/03066150.2011.583642

Muñoz, C. 2008. La reinvención de la comunidad: cambio social y estrategias de adaptación en el México rural. Un caso de estudio. In K. Appendini and G. Torres, editors. ¿Ruralidad sin agricultura? Perspectivas multidisciplinarias de una realidad fragmentada. First edition. El Colegio de México, Centro de Estudios Económicos, Mexico City, Mexico.

Nisbet, M. C., and M. Huge. 2007. Where do science debates come from? Understanding attention cycles and framing. Pages 193-230 in D. Brossard, J. Shanahan, and T. C. Nesbitt. The media, the public and agricultural biotechnology. $\mathrm{CAB}$ International, Wallingford, UK.

Pachicho, D., and S. Fujisaka, editors. 2004. Scaling up and out: achieving widespread impact through agricultural research. Centro Internacional de Agricultura Tropical, Cali, Colombia.

Palekar, S. Undated. The philosophy of spiritual farming: zero budget natural farming. Revised fourth edition. Zero Budget Natural Farming Research, Development \& Extension Movement, Amravati, Maharashtra, India.

Perfecto, I., J. H. Vandermeer, and A. L. Wright. 2009. Nature's matrix: linking agriculture, conservation and food sovereignty. Earthscan, London, UK.

Rosset, P. M. 2009. La guerra por la tierra y el territorio. Pages 159-175 in Centro Indigena de Capacitacion Integral Universidad de la Tierra (CIDECI-UNITIERRA), editor. Primer coloquio internacional in memoriam Andrés Aubry: planeta tierra: movimientos antisistémicos. CIDECIUNITIERRA Ediciones, San Cristobal de las Casas, Chiapas, Mexico.

Rosset, P. M. 2011. Food sovereignty and alternative paradigms to confront land grabbing and the food and climate crises. Development 54(1):21-30. http://dx.doi.org/10.1057/d ev.2010.102
Rosset, P. M., B. Machín Sosa, A. M. Roque Jaime, and D. R. Ávila Lozano. 2011. The Campesino-to-Campesino agroecology movement of ANAP in Cuba: social process methodology in the construction of sustainable peasant agriculture and food sovereignty. Journal of Peasant Studies 38(1):161-191. http://dx.doi.org/10.1080/03066150.2010.538584

Scoones, I., N. Marongwe, B. Mavedzenge, J. Mahenehene, F. Murimbarimba, and C. Sukume. 2010. Zimbabwe's land reform: myths and realities. Boydell \& Brewer, Suffolk, UK.

Sesia, P. 2003. Repeasantization and decommodification of Indigenous agriculture: coffee, corn and food security in Oaxaca. Pages 81-126 in C. Walsh, E. E. Ferry, G. Soto Laveaga, P. Seisa, and S. Hill, editors. The social relations of Mexican commodities: power, production, and place. Center for U.S.-Mexican Studies, University of California, San Diego, California, USA.

Sevilla Guzmán, E. 2007. De la sociología rural a la agroecología. Ediciones Icaria, Barcelona, Spain.

Sevilla Guzmán, E., and J. M. Alier. 2006. New rural social movements and agroecology. Pages 468-475 in P. J. Cloke, T. Marsden, and P. Mooney, editors. Handbook of rural studies. Sage, London, UK.

Starr, A., M. E. Martínez-Torres, and P. M. Rosset. 2011. Participatory democracy in action: practices of the Zapatistas and the Movimento Sem Terra. Latin American Perspectives 38(1):102-119. http://dx.doi.org/10.1177/0094582X10384214

Stédile, J.P. 2008. La ofensiva de las empresas transnacionales sobre la agricultura. Rebelion. [online] URL: http://www.reb elion.org/noticia.php?id=77961.

Teubal, M. 1987. Internationalization of capital and agroindustrial complexes: their impact on Latin American agriculture. Latin American Perspectives 14(3):316-364. http ://dx.doi.org/10.1177/0094582X8701400304

United States Department of Agriculture (USDA). 2011. 2011 farm sector income forecast. USDA Economic Research Service, Washington, D.C., USA. [online] URL: http://www. ers.usda.gov/topics/farm-economy/farm-sector-income-finances/2012farm-sector-income-forecast.aspx.

United States Census Bureau. 2010. Section 17: agriculture. U.S. Census Bureau, Washington, D.C., USA. [online] URL: http://www.census.gov/prod/2009pubs/10statab/agricult.pdf

van der Ploeg, J. D. 2008. The new peasantries: struggles for autonomy and sustainability in an era of empire and globalization. Earthscan, London, UK. 
van der Ploeg, J. D. 2010. The peasantries of the twenty-first century: the commoditisation debate revisted. Journal of Peasant Studies 37(1):1-30. http://dx.doi.org/10.1080/030661 $\underline{50903498721}$

von der Weid, J. M. 2000. Scaling up, and scaling further up: an ongoing experience of participatory development in Brazil. Assessoria e Serviços a Projectos em Agricultura Alternativa (AS-PTA), Sao Paulo, Brazil. [online] URL: http://www.fao. org/docs/eims/upload/215152/AS-PTA.pdf.

Wezel, A., S. Bellon, T. Doré, C. Francis, D. Vallod, and C. David. 2009. Agroecology as a science, a movement and a practice: a review. Agronomy and Sustainable Development 29(4):503-515. http://dx.doi.org/10.1051/agro/2009004

World Commission on Dams. 2000. Dams and development. Earthscan, London, UK.

Zoomers, A. 2010. Globalisation and the foreignisation of space: seven processes driving the current global land grab. Journal of Peasant Studies 37(2):429-447. http://dx.doi.org/1 $\underline{0.1080 / 03066151003595325}$ 